\title{
Sequence stratigraphy, basin morphology and sea-level history for the Permian Kapp Starostin Formation of Svalbard, Norway
}

\author{
DAVID P. G. BOND*†, DIERK P. G. BLOMEIER $\ddagger$, ANNA M. DUSTIRA \\ PAUL B. WIGNALLף, DANIEL COLLINS\|, THOMAS GOODE\#,

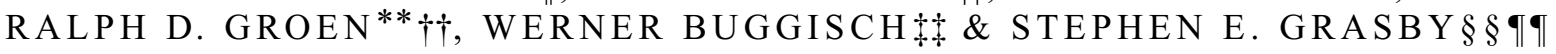 \\ * School of Environmental Sciences, University of Hull, Hull HU6 7RX, United Kingdom \\ Millennia Stratigraphic Consultants, 35 Swansfield, Lechlade-on-Thames, Gloucestershire GL7 3SF, United Kingdom \\ $\S$ Statoil, Mølnholtet 42, 9414 Harstad, Norway \\ -SSchool of Earth and Environment, University of Leeds, Leeds LS2 9JT, United Kingdom \\ ||Earth Science and Engineering Department, Imperial College, London SW7 2AZ, United Kingdom \\ \#IGas Energy PLC, 7 Down Street, London W1J 7AJ, United Kingdom \\ ** Maersk Oil and Gas, Britanniavej 10, 6700 Esbjerg, Denmark \\ $\dagger \dagger$ Faculty of Earth and Life Science, VU University Amsterdam, De Boelelaan 1085-1087, 1081 HV Amsterdam, The \\ Netherlands \\ †Geozentrum Nordbayen, Universität Erlangen-Nürnberg, Schlossgarten 5, 91054 Erlangen, Germany \\ $\S \S$ Geological Survey of Canada, 3303 33rd Street N.W., Calgary, Alberta T2L 2A7, Canada \\ qाDepartment of Geoscience, University of Calgary, 2500 University Drive NW, Calgary, Alberta T2N 1N4, Canada
}

(Received 9 March 2016; accepted 9 November 2016; first published online 9 January 2017)

\begin{abstract}
Based on seven measured sections from Svalbard, the marine strata of the Permian Kapp Starostin Formation are arranged into seven transgressive-regressive sequences (TR1-TR7) of $c .4-$ $5 \mathrm{Ma}$ average duration, each bound by a maximum regressive surface. Facies, including heterozoandominated limestones, spiculitic cherts, sandstones, siltstones and shales, record deposition within inner, middle and outer shelf areas. The lowermost sequence, TR1, comprises most of the basal Vøringen Member, which records a transgression across the Gipshuken Formation following a hiatus of unknown duration. Temperate to cold, storm-dominated facies established in inner to middle shelf areas between the latest Artinskian and Kungurian. Prolonged deepening during sequences TR2 and TR3 was succeeded by a long-term shallowing-upward trend that lasted until the latest Permian (TR4-TR7). A major depocentre existed in central and western Spitsbergen while to the north, Dickson Land remained a shallow platform, leading to a shallow homoclinal ramp in NE Spitsbergen and Nordaustlandet. The Middle Permian extinction (late Capitanian) is recorded near the base of TR6 in deeper parts of the basin only; elsewhere this sequence is not recorded. Likewise the youngest sequence, TR7, extending to the upper formational contact of latest Permian age, is found only in the basin depocentre. Comparison with age-equivalent strata in the Sverdrup Basin of Canada reveals a remarkably similar depositional history, with, for example, two (third-order) sea-level cycles recorded in the Late Permian of both regions, in keeping with the global record. Sequence stratigraphy may therefore be a powerful correlative tool for onshore and offshore Permian deposits across NW Pangaea.
\end{abstract}

Keywords: Spitsbergen, stratigraphy, extinction, facies analysis.

\section{Introduction}

The Permian Kapp Starostin Formation (Tempelfjorden Group) of Svalbard comprises a superbly exposed succession of biogenic cherts and carbonates with minor siliciclastic deposits (sandstones, siltstones and shales). The strata provide a window into the Permian Chert Event, an unprecedented $30 \mathrm{Ma}$ long interval of biogenic chert deposition that extended across the northern margin of Pangaea and is recorded in Arctic Canada (Sverdrup Basin), eastern North Greenland (Wandel Sea Basin), Russia (Timan-Pechora Basin),

†Author for correspondence: d.bond@hull.ac.uk the Barents Sea (the Finnmark Platform and Stappen High offshore) and onshore Svalbard (the latter is shown in Fig. 1) (Murchey \& Jones, 1992; Stemmerik, 1997; Beauchamp \& Baud, 2002; Larssen et al. 2005). The Barents Sea has been the subject of explorationmotivated research for several decades (Ronnevik \& Motland, 1981; Stemmerik \& Worsley, 2005), resulting in a number of seismic-based sequence stratigraphic studies and correlations between offshore strata and the age-equivalent Kapp Starostin Formation on Spitsbergen and Nordaustlandet in the Svalbard archipelago (e.g. Cecchi, 1993; Cecchi, Markello \& Waite, 1995; Ehrenberg et al. 1998; Colpaert et al. 2007). 


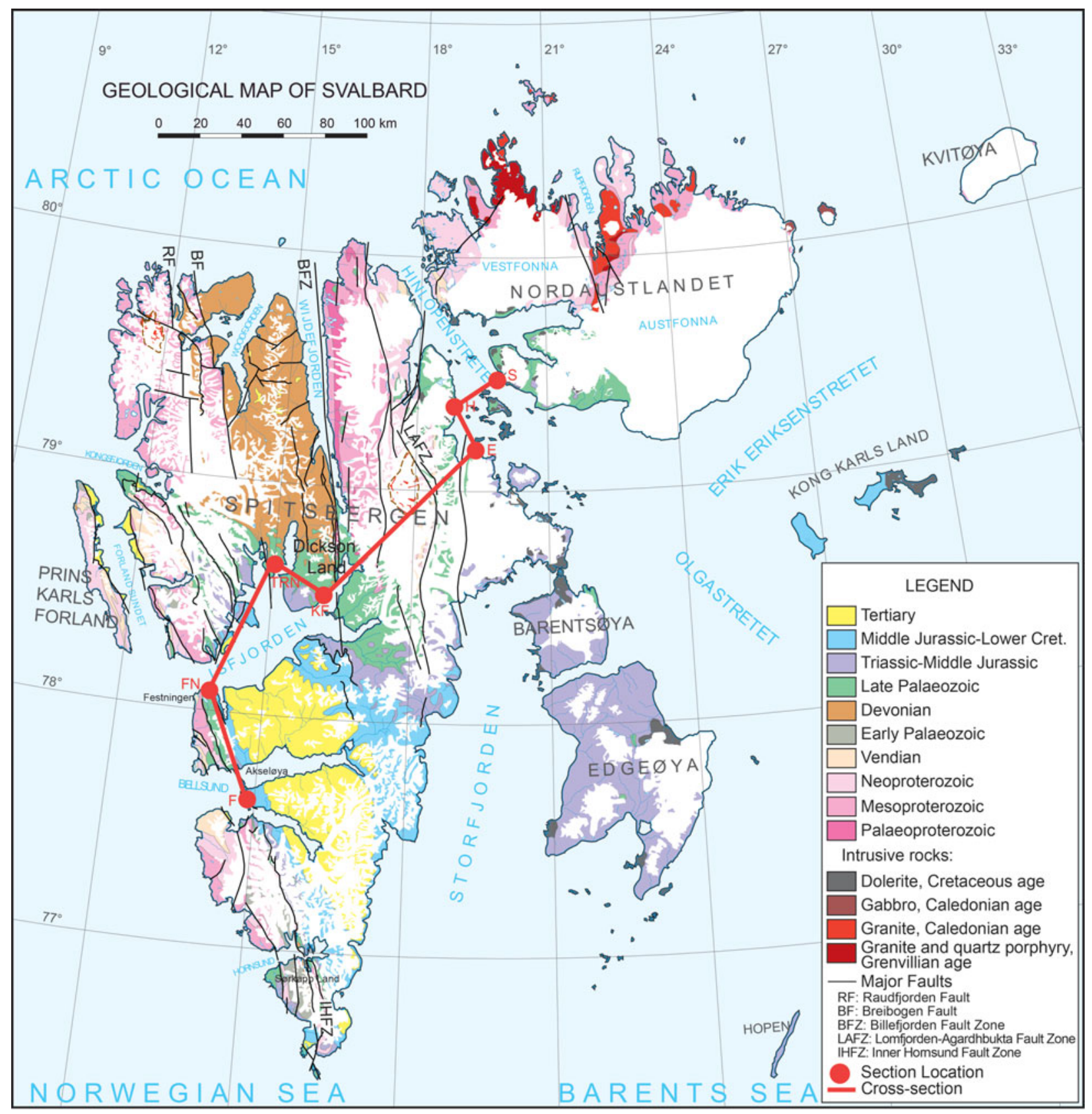

Figure 1. (Colour online) Geological map of the Svalbard archipelago (excluding Bjørnøya), showing the section locations within NE Svalbard (E, H, S) and central Spitsbergen (F, FN, KF, TRN). The transect used for the section correlation (Figs 4, 5) and the interpreted cross-section (Fig. 7) is marked by a red line.

Onshore extensive outcrops of the Kapp Starostin Formation provide opportunity for a detailed sequence stratigraphic study and analyses of the geological setting and basin morphology. The Svalbard sequences reveal substantial lateral and vertical thickness and facies changes, varying geometry and stratigraphic relationships of sedimentary deposits, large-scale sedimentary patterns including the record of the Middle Permian mass extinction, and post-depositional deformation.

Previous sequence stratigraphic studies of the Kapp Starostin Formation have largely focused on correlation with contemporaneous offshore (Barents Sea) strata and were based on a limited number of sections (e.g. Stemmerik \& Worsley, 1989; Stemmerik, 1997; Ehrenberg et al. 1998, 2000, 2001). Here we present a more comprehensive sequence stratigraphic model for the Kapp Starostin Formation, based on seven onshore sections spanning the greater portion of the Svalbard archipelago. This is intended to facilitate correlation of the onshore and offshore strata of the Barents Sea and its counterparts across northern Pangaea. Detailed facies analysis provides the main tool for correlating the study sections, resulting in the interpretation of lateral facies relationships and the basin morphology, and a reconstruction of the sea-level history for the Artinskian to Changhsingian depositional period of the Kapp Starostin Formation. 


\section{Regional setting}

Permian bedrocks are exposed at a multitude of localities across Svalbard (Fig. 1). In most areas, excluding Bjørnøya, the strata are arranged into two fundamentally contrasting lithostratigraphic units: the Early Carboniferous to Early Permian Gipsdalen Group and the Early to Late Permian Tempelfjorden Group (Fig. 2). The Gipsdalen Group (SerpukhovianArtinskian) comprises mainly carbonates (limestones and dolostones) and evaporites (gypsum and anhydrite), characterised by fully photozoan (Wordiekammen Formation) to reduced photozoan/heterozoan biotic assemblages (Gipshuken Formation; Cutbill \& Challinor, 1965; Lauritzen 1981a, 1981b; Blomeier et al. 2011). Sediments and fossils reflect opento restricted-marine carbonate platform environments and coastal settings (intertidal to supratidal lagoons, mudflats and sabkhas) under a warm, dry climate. The boundary between the Gipsdalen Group (Gipshuken Formation) and Tempelfjorden Group (Kapp Starostin Formation) is marked by a major hiatus of Artinskian age. This manifests as a disconformity resulting from subaerial exposure of extended platform areas and the subsequent erosion of the uppermost Gipsdalen Group strata prior to, or during transgression, and the onset of Kapp Starostin Formation sedimentation (Dallmann, 1999; Ehrenberg et al. 2001; Blomeier et al. 2011; Fig. 2).

In contrast to the Gipsdalen Group, the sedimentary facies of the Tempelfjorden Group (Artinskian to Changhsingian stages; Fig. 2) consist predominantly of light and dark spiculitic cherts interbedded with locally occurring siliceous shales and siltstones, glauconitic sandstones and silicified, fossiliferous limestones (Dallmann, 1999) with a fully heterozoan faunal assemblage. During the deposition of the Tempelfjorden Group, Svalbard formed part of a broad, epicontinental shelf at the northern margin of Pangaea, which experienced a period of prolonged biogenic chert deposition due to persistent cool-water conditions (Murchey \& Jones, 1992; Beauchamp \& Baud, 2002; Beauchamp \& Grasby, 2012; Grasby et al. 2015, 2016). The strata record open-marine nearshore to deeper offshore environments.

Synsedimentary tectonic activity in the Svalbard region during the Early Carboniferous (Mississippian) created a series of local rift basins across the archipelago. By the Late Carboniferous (Pennsylvanian), rift movements ceased and the entire region experienced a more uniform subsidence during the Permian, although higher subsidence rates and local downwarping may have continued to some extent near previous graben structures, affecting sedimentation, palaeobathymetry and topography during deposition of the Tempelfjorden Group (Steel \& Worsley, 1984; Stemmerik \& Worsley, 1989). Accordingly, the thickness of the Tempelfjorden Group varies substantially, from a maximum of $460 \mathrm{~m}$ in western Svalbard $(>400 \mathrm{~m}$ on Akseløya, and $380 \mathrm{~m}$ at the Kapp Starostin Form- ation type section at Festningen, outer Isfjorden) at the deepest points in the depositional basin, to only a few metres thickness at Hornsund in southern Spitsbergen. Further south still, at Sørkapp Land, the Kapp Starostin Formation completely wedges out against the margins of the Sørkapp-Hornsund High (Fig. 1; Siedlecka, 1970; Hellem \& Worsley, 1978; Dallmann, 1999).

The Tempelfjorden Group is divided into the Kapp Starostin Formation, the most widespread and predominant formation across Svalbard, and the contemporaneous Tokrossøya Formation (in Hornsund) and Miseryfjellet Formation (on Bjørnøya; Fig. 2). The latter two formations formed in contemporaneous depositional basins marked by distinct but similar sedimentological and palaeogeographic developments (Dallmann, 1999). The Kapp Starostin Formation is further subdivided into several members, of which only the Vøringen Member at the base of the formation is formally defined. Above the Vøringen Member, the strata of the Kapp Starostin Formation are arranged into a number of informal, local members, not referred to in this study. The upper boundary of the Kapp Starostin Formation to the Vardebukta and Vikinghøgda Formations of the latest Permian to Middle Triassic Sassendalen Group is sharp, condensed and conformable, and marked by the onset of marine shales and siltstones and the termination of biogenic deposits such as cherts (Ehrenberg et al. 2001; Dustira et al. 2013; Grasby et al. 2015, 2016). Carbonate producers disappeared c. $40 \mathrm{~m}$ below this boundary at the type section; skeletal limestones are not seen in the topmost metres of the Kapp Starostin Formation. This level is considered to be immediately below the Middle Permian mass extinction that saw the disappearance of $>80 \%$ of brachiopod taxa (Bond et al. 2015).

Biostratigraphic control is poor but there have been studies based on bryozoan, brachiopod, coral, conodont and palynomorph assemblages that provide approximate age control for the Kapp Starostin Formation (Szaniawski \& Malkowski, 1979; Biernat \& Birkenmajer, 1981; Nakamura, Kimura \& Winsnes, 1987; Nakrem, 1988, 1991; Stemmerik, 1988; Nakrem, Nilsson \& Mangerud, 1992; Mangerud \& Konieczny, 1993; Buggisch et al. 2001; Chwieduk, 2007). More recently, Bond et al. (2015) attempted to date the upper part of the formation using chemostratigraphy $\left(\delta^{13} \mathrm{C}_{\text {org }}\right.$ and ${ }^{87} \mathrm{Sr} /{ }^{86} \mathrm{Sr}$ ratios $)$. Conodonts and foraminifera indicate a late Artinskian to Kungurian depositional period for the Vøringen Member, while palynomorphs, brachiopods, bryozoans and conodonts indicate Capitanian ages for the upper part of the formation (Nakrem, Nilsson \& Mangerud, 1992). The lack of reliable age-diagnostic taxa in the uppermost metres of the Kapp Starostin Formation has led to considerable disagreement on age assignment for its youngest sediments and a level of uncertainty regarding the positioning of the Permian-Triassic boundary (Wignall, Morante \& Newton, 1998). However, $\delta^{13} \mathrm{C}_{\text {org }}$ chemostratigraphic studies on bulk samples from central 


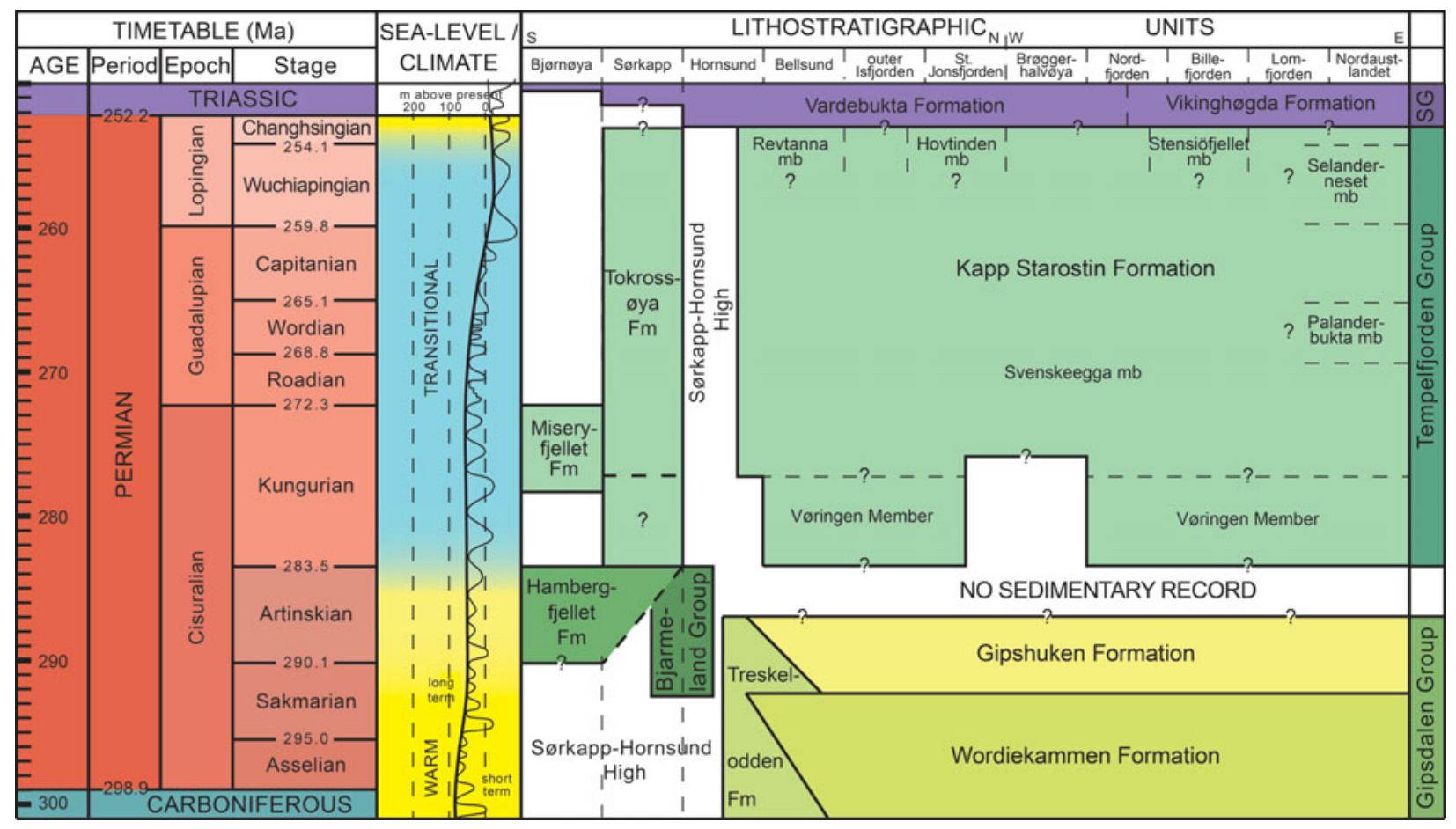

Figure 2. (Colour online) Permian chronostratigraphy (based on the International Chronostratigraphic Chart 2015/01), sea-level history (modified from Haq \& Schutter, 2008) and lithostratigraphic system of Svalbard (modified from Dallmann, 1999). Fm = Formation; $\mathrm{mb}=$ member (informal); $\mathrm{SG}=$ Sassendalen Group .

Spitsbergen indicate that the top of the Kapp Starostin Formation is of latest Permian (Changhsingian) age, and that the Permian-Triassic boundary lies within the lowermost metres of the overlying Sassendalen Group (Wignall, Morante \& Newton, 1998; Dustira et al. 2013; Bond et al. 2015; Wignall et al. 2016).

\section{Methods}

We measured seven sections across Spitsbergen and Nordaustlandet (from southwest to northeast: Forkastningsdalen; Festningen; Tålmodryggen; Kapp Fleur de Lys; Eremitten; Hódbreen; and Selanderneset; Fig. 1), varying in thickness from 100 to $380 \mathrm{~m}$, between the years 2005 and 2012. Bed thicknesses (terminology after Tucker, 2003), colours, lithologies, textures, sedimentary structures, macrofossils and the stacking pattern of the strata were recorded in the field, and more than 400 samples were collected and thin-sectioned for subsequent detailed microfacies analysis (Blomeier et al. 2011, 2013). This data provides the basis for the correlation of these seven vertical sections and the sequence stratigraphic arrangement introduced here. The petrography of the Festningen section (section FN) in western Spitsbergen has been examined in detail using a petrographic microscope and scanning electron microscope in backscatter mode. Carbonates are described according to the classification scheme of Dunham (1962), whilst mixed siliciclastic-carbonate deposits are classified after Mount (1985) and siliciclastic sediments are classified after Wentworth (1922).

\section{Facies and depositional setting of the Kapp Starostin Formation}

Depositional sequences within the Kapp Starostin Formation strata are identified based on their largescale stacking patterns, as well as facies and microfacies development, which generally reflect palaeowater depth and thus provide a reliable indicator of accommodation space. We use sedimentary facies in association with sedimentation patterns to infer relative sea-level changes within the studied sections. Detailed facies analyses of the Kapp Starostin Formation were performed by Blomeier et al. $(2011,2013)$ and our depositional model (Fig. 3) is based on the three main depth-dependent facies associations established in those publications. These serve as the basis for the sequence stratigraphic model developed here, which derives from the interpretation of facies changes in all seven sections within this study (Figs 4, 5). A total of 11 facies types are recognized within the Kapp Starostin Formation strata (Blomeier et al. 2011, 2013), and are grouped into three facies associations (limestones, spiculitic cherts, and siliciclastics) that record a range of inner, middle and outer shelf depositional environments (Table 1; Fig. 3).

\section{4.a. Inner-shelf facies association}

The inner shelf refers to the zone stretching from the lower shoreface (and fair weather wave base, FWWB) to the middle-shelf transitional zone (Fig. 3). The inner-shelf facies association includes coarsegrained, brachiopod-dominated rudstones with minor 
to

$\begin{array}{ll}\text { Mudstone } & \\ \text { Black shale } & 3 \mathrm{c} \\ \text { Siltstone } & 3 \mathrm{~d}\end{array}$

and glauconite grains. 


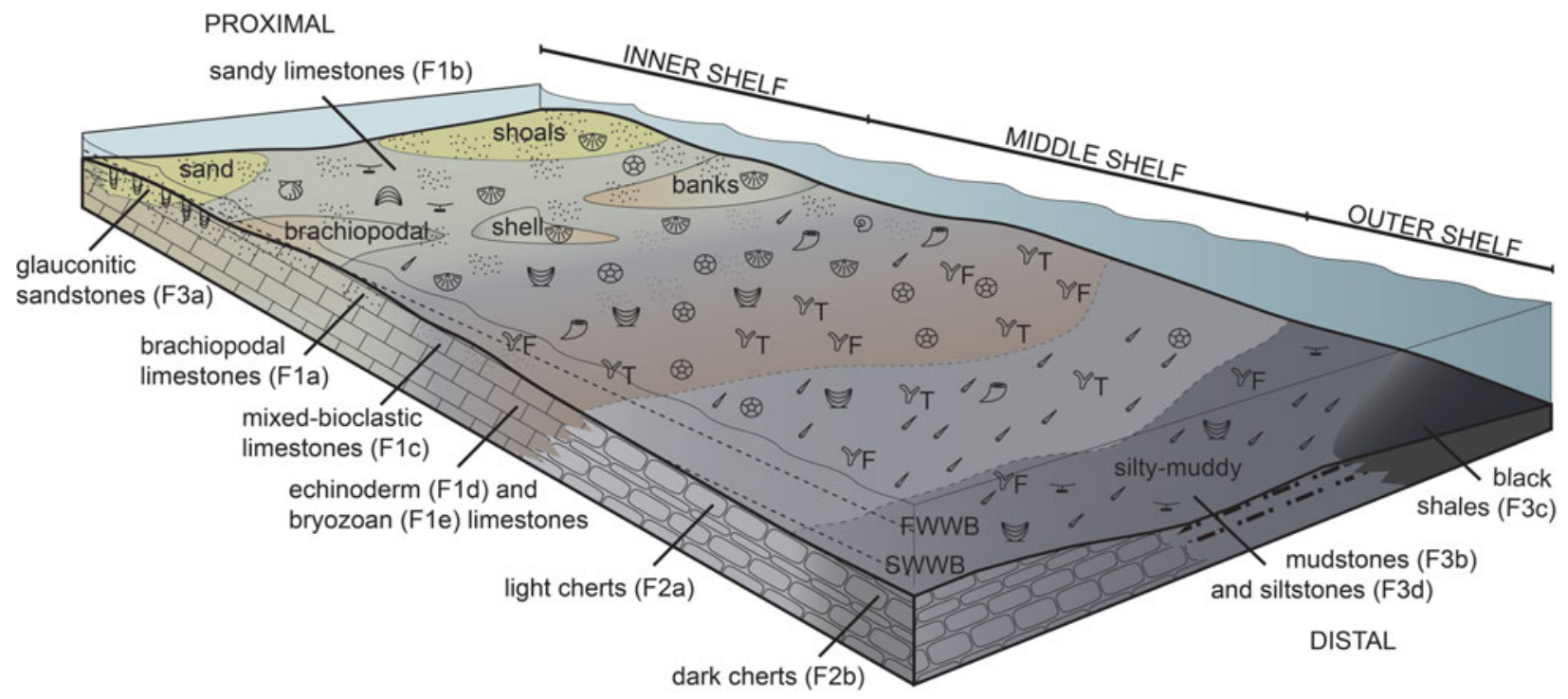

Figure 3. (Colour online) Schematic depositional model for the Kapp Starostin Formation, showing main facies associations and fossil assemblages of the inner, middle and outer shelf zones (modified from Blomeier et al. 2013). FWWB = fair weather wave base; $\mathrm{SWWB}=$ storm weather wave base. Facies descriptions are provided in Table 1.

grainstones and packstones (facies 1a, e.g. Fig. 6a; Table 1), fine-grained, sandy, bioclastic, peloidal grainstones with minor wackestones and packstones (facies 1b), mixed-bioclastic wackestones, grainstones, floatstones and rudstones (facies $1 \mathrm{c}$, which is also present in some middle shelf settings). Some sections expose thin- to thick-bedded, massive sandstones (facies 3a) that are also interpreted as inner shelf deposits because they are extremely well-sorted and winnowed as a result of prolonged exposure to high-energy currents that perhaps occurred during storms (e.g. Blomeier et al. 2011, 2013).

\section{4.b. Middle-shelf facies association}

The middle shelf area extends from the middle shelf transitional zone near fair weather wave base (FWWB) to the storm weather wave base (SWWB). Coarsegrained, echinoderm- (facies 1d) and bryozoandominated (facies 1e) wackestones and floatstones and minor packstones, grainstones and rudstones are prevalent on the middle shelf, where they form prominent, thick- to medium-bedded bed-sets mainly comprising allochthonous debris and, more rarely, local autochthonous build-ups. With increasing water depth, the brachiopod constituents that dominate the inner-shelf facies associations gradually decrease in abundance. The echinoderm- and bryozoan-dominated limestones pass distally into thick- to medium-bedded, nodular to massive, light cherts (facies 2a), resulting from the accumulation of siliceous sponge spicules on extended submarine flats. Ehrenberg et al. (2001) report localized bryozoan bioherms embedded in the light cherts, suggesting that in some middle shelf settings the two lithologies coexisted, perhaps on a structural high within the middle shelf. We do not see clear evidence of reef fabrics in our facies $1 \mathrm{~d}$ and $1 \mathrm{e}$, however.

\section{4.c. Outer-shelf facies association}

The outer shelf extends from around SWWB towards the deepest areas of the basin. The facies association is characterized mainly by thick successions of thinto medium-bedded, massive, dark spiculitic cherts (facies 2 b, e.g. Fig. 6b), locally interbedded with silicified mudstones (facies $3 b$ ) and black shales (facies 3c), forming partings and thin-bedded horizons, (Blomeier et al. 2013). In addition, intercalations of homogeneous, dark siltstones (facies 3d, e.g. Fig. 6c) occur in central and western Spitsbergen (sections F, FN, TRN). Abundant burrows and bioturbation within the dark cherts and fine horizontal lamination within some of the shales are indicative of varying bottom water oxygen levels on the outer shelf. Occasionally intercalated, thin- to medium-bedded limestones (wackestones to grainstones) marked by coarse-grained skeletal debris from the middle and inner shelf zones are interpreted as distal tempestites, reflecting the storm-related import of shallow-marine material into the most distal and deepest shelf zones (Blomeier et al. 2013).

\section{Sequence stratigraphic arrangement}

Due to the absence of subaerial unconformities, which might otherwise be used as sequence boundaries, we have adopted the transgressive-regressive (T-R) sequence approach introduced by Embry \& Johannessen (1992). This approach uses the subaerial unconformity as the unconformable portion of the boundary (not recorded in our sequences), and the maximum regressive surface as the correlative conformity (recorded in our sequences). Thus, individual T-R sequences are bound by maximum regressive surfaces (MRSs), not sequence boundaries of the traditional Exxon sequence stratigraphic model. This approach works well in more distal sections which lack a subaerial erosional 


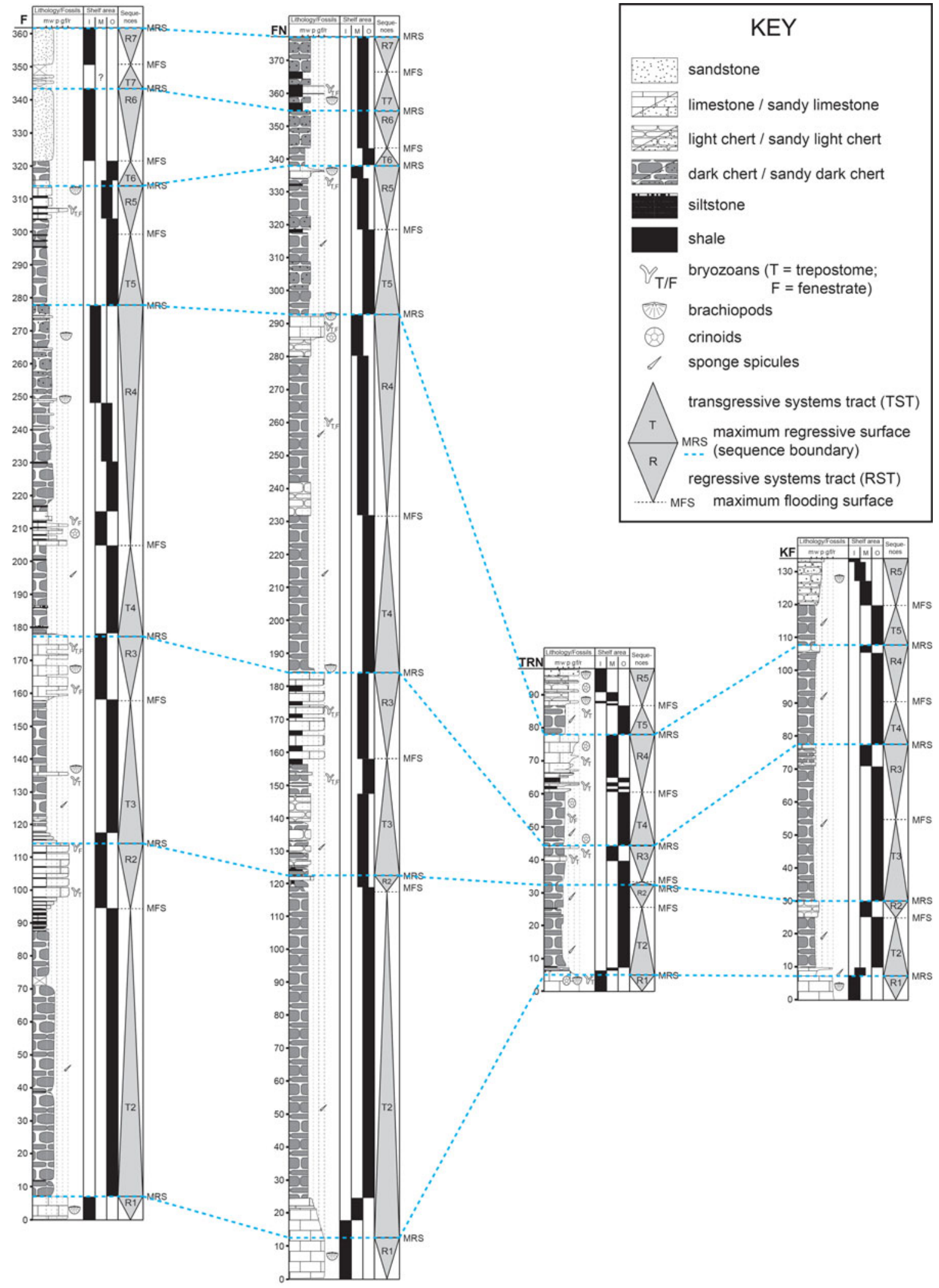

Figure 4. (Colour online) Correlation of the vertical sections located in western and central Spitsbergen: Forkastningsdalen (F), Festningen (FN), Tålmodryggen (TRN), Kapp Fleur de Lys (KF; see Fig. 1 for section locations), showing section and bed thickness, main lithologies and fossils, depositional environments (inner, middle, outer shelf), and presumed third-order depositional sequences (grey cones). Abbreviations used for lithological descriptions follow the Dunham (1962) scheme: $\mathrm{m}=$ mudstone; $\mathrm{w}=\mathrm{wackestone} ; \mathrm{p}=$ packstone; $\mathrm{g}=$ grainstone; $\mathrm{f} / \mathrm{r}=$ floatstones and rudstones. Abbreviations used for shelf position: $\mathrm{I}=$ inner shelf; $\mathrm{M}=$ middle shelf; $\mathrm{O}=$ outer shelf. 


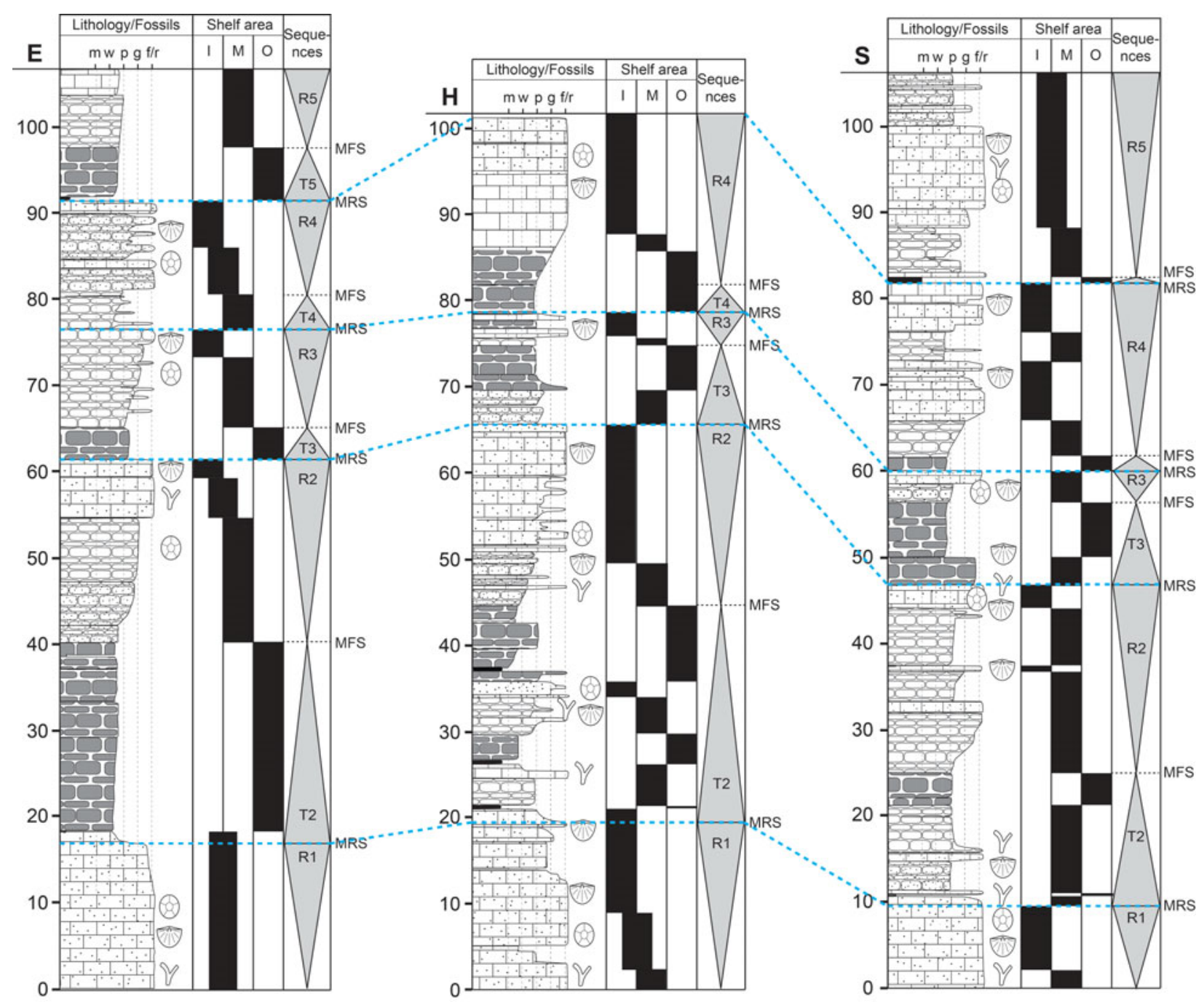

Figure 5. (Colour online) Correlation of the vertical sections located in NE Svalbard: Eremitten (E), Hódbreen (H) and Selanderneset (S; see Fig. 1 for section locations), showing section and bed thickness, main lithologies and fossils, depositional environments (inner, middle, outer shelf), and presumed third-order depositional sequences. Symbols and abbreviations as in Figure 4.

unconformity. A single T-R sequence can be further divided into a fining-upward transgressive systems tract (TST) below, and a coarsening-upward regressive systems tract (RST) above, with the maximum flooding surface (MFS) being the mutual boundary. We have defined multiple T-R sequences in the Kapp Starostin Formation, each bound by an MRS that caps a succession of regressive sediments that coarsen upward as a result of decreasing accommodation space. The oldest of these in our sections is characterized by a ravinement surface - a transgressive surface of erosion generated by wave erosion near the base of the shoreface (see Section 5.a, below); several others are characterized by sediment starvation and the formation of firmgrounds. The T-R sequences in the Kapp Starostin Formation can be divided into their component systems tracts using conspicuous maximum flooding surfaces. These are distinctive surfaces of non-deposition, sediment starvation and condensation that tend to cap the finest grained sediments of the TSTs and precede the onset of coarsening-upward cycles (RSTs). Most of the MFSs seen in the Kapp
Starostin Formation can be traced across the basin and correlated between the study sections.

We have identified seven T-R sequences (TR1-TR7) within the Kapp Starostin Formation (Figs 4, 5) of which all apart from the oldest sequence record complete trangressive and regressive systems tracts. The total duration of the Formation's depositional period was c. $30 \mathrm{Ma}$ (latest Artinskian, at c. $283.5 \mathrm{Ma}$ (Cohen et al. 2013, updated) to late Changhsingian, $c$. $252.5 \mathrm{Ma}$ ) and so the T-R sequences are probably third-order stratigraphic cycles with average durations of c. 4-5 Ma (e.g. Vail, 1991; Coe et al. 2003). Although there seems to be a consensus that cycles in the Kapp Starostin Formation are the result of third-order eustatic cycles, opinion differs on the absolute number of cycles that are recorded (e.g. Ezaki, Kawamura \& Nakamura, 1994; Stemmerik, 1997; Ehrenberg et al. 2001). However, our study is in agreement with Ehrenberg et al. (2001), who identified seven sequences in the expanded Akseløya section; we have identified seven T-R cycles in the nearby expanded sections at Forkastningsdalen (F) and at Festningen (FN). The 

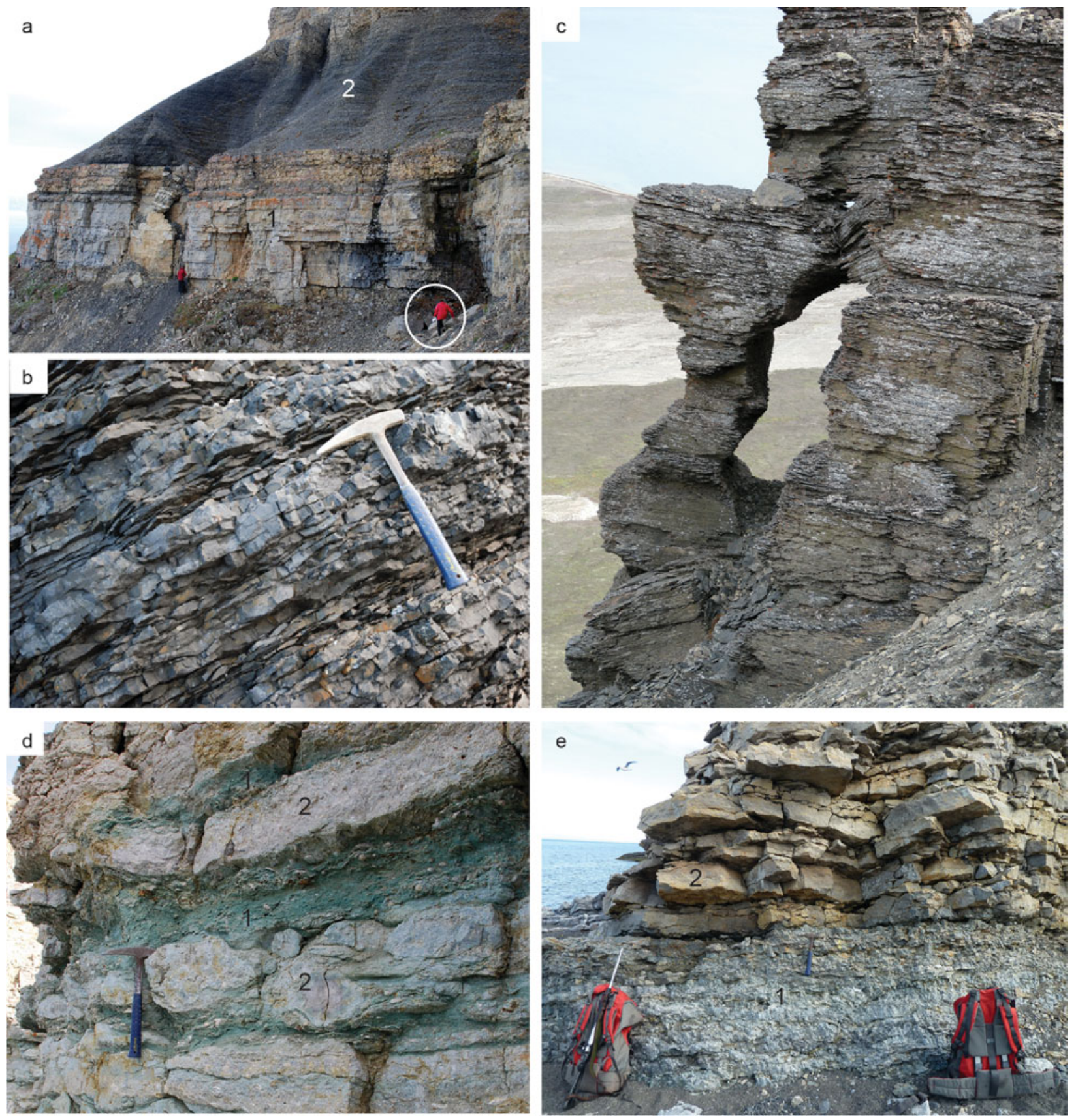

Figure 6. (Colour online) Photographs of the dominant lithologies and facies types of the Kapp Starostin Formation. (a) At Kapp Fleur de Lys (section KF), the Vøringen Member (1), which mainly consists of coarse-grained, brachiopod-dominated skeletal floatstones and rudstones is overlain by a thick succession (2) of dark cherts interbedding with black shales and silicified mudstones. Person for scale $=1.8 \mathrm{~m}$ tall. (b) Close-up of the dark chert succession overlying the Vøringen Member at Festningen (section FN). The bedding of the medium- to thin-bedded cherts is due to black shale partings and intercalations of thin shale horizons. Hammer for scale $=$ $33 \mathrm{~cm}$ long. (c) A monotonous, several metres thick, horizontally bedded succession of siltstones and paper shales forming a part of sequence TR4 at Tålmodryggen (section TRN). Field of view c. $8 \mathrm{~m}$ high. (d) An intercalation of glauconitic sandstones (1) and coarse-grained, brachiopod-dominated floatstones and rudstones (2) within sequence TR4 at Selanderneset (section S). Hammer for scale. (e) An association of light-coloured, massive cherts (1), overlain by a bed-set of thick- to thin-bedded bryozoan grainstones (2) in sequence TR3 at Festningen (section FN). Hammer (centre of photograph) for scale.

only discrepancy occurs in the interpretation of the basalmost cycles described below.

\section{5.a. Sequence TR1}

Sequence TR1 comprises most of the Vøringen Member of the Kapp Starostin Formation. The lower con- tact of the Vøringen Member with the underlying Gipshuken Formation marks the lowest base level recorded in the investigated strata. This contact is an unconformity that represents a hiatus of unknown duration within the Artinskian Stage (Ehrenberg et al. 2001; Blomeier et al. 2011). The base of the Vøringen Member locally contains strongly reworked and bored 
carbonate extraclasts originating from the underlying Gipshuken Formation, which are interpreted as products of transgressive erosion. The initial flooding at the base of the Vøringen Member was rapid, and as a result the transgressive systems tract part of TR1 is absent, and this interval of time is recorded only by the ravinement surface. Consequently, we see only the RST portion of this sequence, as the newly available accommodation space was filled with coarseningupward, largely inner shelf sediments (Figs 4, 5, 7).

The complete regressive portion of the TR1 depositional sequence varies in thickness from c. $5 \mathrm{~m}$ (section TRN) to $20 \mathrm{~m}$ (section $\mathrm{H}$ in NE Spitsbergen; Figs 4, 5). The facies consist mainly of brachiopodal rudstones and grainstones (facies 1a; Table 1), with minor light cherts (facies 2a) and sandstones (facies 3a) in NE Svalbard. The northernmost sections $(\mathrm{H}$ and $\mathrm{S})$ record a clear vertical facies shift from more offshore (e.g. middle shelf echinodermand bryozoan-dominated wackestones to grainstones, with minor floatstones and rudstones; facies $1 \mathrm{~d}$ and $1 \mathrm{e}$ ) to more nearshore (e.g. inner-shelf sandy brachiopoddominated and bioclastic/peloidal grainstones and rudstones; facies $1 \mathrm{a}$ and $1 \mathrm{~b}$ ) consistent with a regressive systems tract. Thin, sandstone interbeds (facies 3a) also become more common upwards in several sections (e.g. at TRN, E, S, H; see Figs 4, 5).

\section{5.b. Sequence TR2}

Except at Festningen, the contact between TR1 and TR2 (i.e. the MRS that tops TR1) lies within the upper part of the Vøringen Member where a renewed deepening of the depositional area is manifest as a shift to echinoderm- and bryozoan-dominated wackestone and floatstones, with less common packstones, grainstones and rudstones (facies $1 \mathrm{~d}$ and $1 \mathrm{e}$ ) with intercalated light cherts (facies 2a, e.g. at section S), or as a gradual change from brachiopod-dominated rudstones and floatstones to finer-grained wackestones and packstones (e.g. at sections FN, TRN, KF, E, H). Only in section $F$ is the MRS that caps sequence TR1 placed at the very top of the Vøringen Member because no intra-Vøringen facies change is observed (Fig. 7).

Sequence TR2 is the thickest complete transgressive-regressive sequence in the Kapp Starostin Formation, albeit with considerable lateral disparity. TR2 ranges from $<50 \mathrm{~m}$ thick in Dickson Land (sections TRN and KF) and in NE Svalbard (sections E, H, S) to $>100 \mathrm{~m}$ thick in western Spitsbergen (sections F and FN). The TST portion of TR2 saw a deepening that terminated carbonate deposition at the top of the Vøringen Member and led to the onset of chert deposition across the basin (Figs 4, 5, 7). The Vøringen Member is conformably overlain by a thin (up to several decimetres thick) dark shale horizon (facies 3c) in all sections that records deepening and transgression. This shale is succeeded by thick successions of dark, thin- to medium-bedded, spiculitic cherts (facies 2b; maximum thickness of
$95 \mathrm{~m}$ in section $\mathrm{FN}$ ) and silicified mudstones (facies $3 \mathrm{~b}$ ), marking the establishment of silica production in deeper, outer-shelf areas. Frequent shale intercalations and partings hint at parasequence-scale cycles.

At sections $\mathrm{H}$ and $\mathrm{S}$ in NE Svalbard, the dark cherts are less prominent (Fig. 5). Instead, the TST part of TR2 saw deposition of light, nodular cherts and two prominent metre-thick bryozoan-, echinoderm- and brachiopod-dominated floatstone and rudstone beds, suggesting generally shallower palaeowater depths and sedimentation above SWWB on the middle shelf within these areas. Dark cherts (facies $2 b$ ) occur at $\mathrm{H}$ towards the top of the TST, indicating that the prolonged deepening in sequence TR2 eventually resulted in the establishment of outer-shelf depositional conditions there. Note that Ehrenberg et al. (2001) interpreted this package of sediment to be the highstand deposits of their first sequence, capped by an MRS. However, we consider the deep-water nature of this facies is inconsistent with a progradational systems tract and instead interpret this package to be a retrogradational systems tract capped by an MFS. Three to four repeated facies shifts are recorded within this TST at $\mathrm{H}$ (less obviously so at section S; Fig. 5) and these probably record either higher-order (e.g. fourth- or fifthorder) sequences that resulted from high-frequency sea-level fluctuations, or the influx of distal tempestites (Blomeier et al. 2013).

An MFS caps the thick successions of dark cherts and mudstones, above which the RST sees the sequence grade into a c. 20-25 m thick succession, firstly of lighter cherts (facies 2a) and then ruditic limestones, predominantly belonging to facies $1 \mathrm{~d}$ and $1 \mathrm{e}$ (echinoderm- and bryozoan-dominated) in NE Svalbard (sections E, H, S; Fig. 5). These record a shift from outer to middle shelf environments in the NE. On Dickson Land (sections TRN and KF) the same change in shelf position is recorded by a thinner, more subtle coarsening upwards within darker (facies $2 b$ ) and lighter (facies 2a) cherts. Further west, middle shelf bryozoan-dominated floatstones and rudstones (facies 1e) are again developed at the top of this RST, especially at section $\mathrm{F}$, where they reach $17 \mathrm{~m}$ in thickness.

Overall, the net effect of sequence TR2 is one of substantial deepening across the entire basin such that middle to outer shelf depositional environments became widely established across Svalbard (Fig. 7).

\section{5.c. Sequence TR3}

The TR2/TR3 boundary is marked by an MRS that records a renewed deepening in sedimentary facies, and a transition from inner to middle shelf limestone facies below (predominantly floatstones and rudstones but also packstones in the basin depocentre), to middle to outer shelf cherts above. At Festningen and Tålmodryggen (sections FN, TRN; Fig. 4), this level is marked by intensely bioturbated dark cherts (facies 2b) with abundant Thalassinoides and Skolithos burrows on their upper surfaces. These probably reflect 


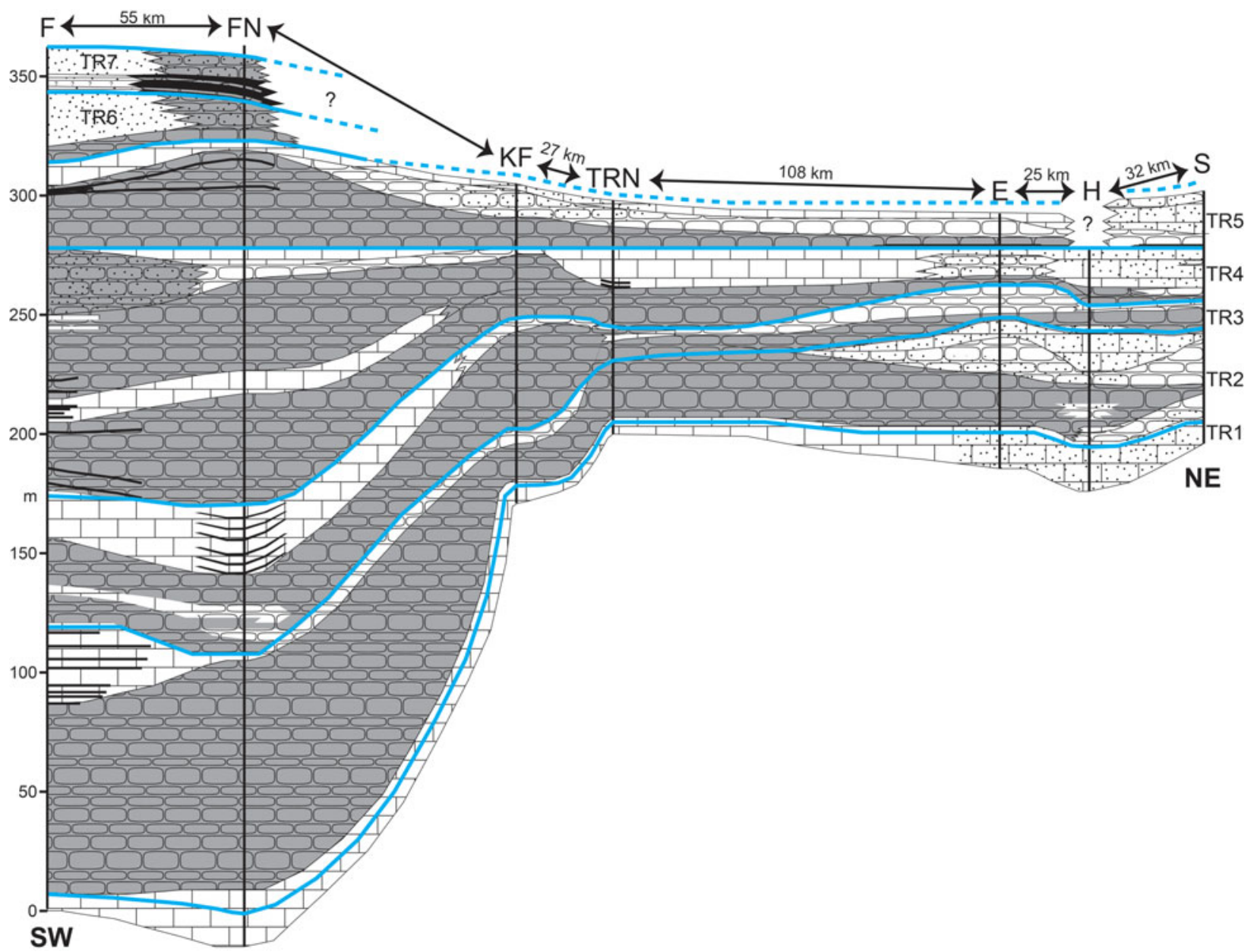

Figure 7. (Colour online) Cross-section through Spitsbergen and Nordaustlandet, showing interpreted facies/sequence correlations and basin morphology along the studied section sites. Blue lines = maximum regressive surfaces (MRS) that bound individual TR sequences. The MRS at the top of sequence TR4 is used as a tie-point because this is the uppermost MRS that is recorded in all seven sections. See Figure 1 for section locations and transect line; see Figure 4 for key to lithological symbols.

condensation and sediment-starved conditions, and the formation of firmgrounds at the onset of the TST part of TR3.

In NE Svalbard, the MRS is marked by an abrupt transition from sandy rudstones and floatstones (facies $1 \mathrm{~d}$ and 1e) to dark cherts (facies 2a). In all three NE Svalbard sections (E, H, S; Fig. 5) this level is notable for a level of intense glauconitization that extends downwards for a few metres (into the sandy limestones). We interpret this to be the product of sediment starvation in accommodation-starved nearshore (inner shelf) environments around the end of the RST and at the onset of transgression (e.g. Boreen \& James, 1995; Blomeier et al. 2013).

The TST deposits in sequence TR3 have considerable lateral thickness variations (Fig. 7), and the MFS that terminates this systems tract has proved difficult to identify in some sections (particularly in outer shelf settings where it is characterized by a very subtle lithological change). Thus, in western Spitsbergen (sections $\mathrm{F}$ and $\mathrm{FN}$ ) this portion of the sequence comprises nearly $40 \mathrm{~m}$ of predominantly dark and light chert (facies 2b and 2a). In Dickson Land, the MFS is charac- terized by a subtle shift from fining upward to coarsening upward within a package of dark cherts at section $\mathrm{KF}$, whereas in the more condensed TRN section the TST consists of just a metre or so of dark, fine-grained chert. In NE Svalbard, the MFS succeeds a 5 and $10 \mathrm{~m}$ fining-upward sequence of dark cherts (facies $2 b$ ).

The RST part of sequence TR3 is recorded in a $20-25 \mathrm{~m}$ thick package of easily correlated, largely bryozoan-dominated floatstones and rudstones with minor packstones (facies 1e) at the most expanded F and FN sections (Fig. 4), where they are interbedded with thin carbonate mudstones and black shales respectively (probably the effects of higher-order cyclicity on the shelf). Packstones and grainstones (facies 1e) also develop in Dickson Land (sections TRN and $\mathrm{KF}$ ) where they intercalate with, and cap, a coarseningupward dark chert (facies 2b) sequence that is $c$. 12-22 $\mathrm{m}$ thick. In NE Svalbard, light cherts (facies 2a) coarsen upwards and are eventually succeeded by crinoid- and brachiopod-dominated floatstones and rudstones (facies 1d, 1c and 1a) of the middle to inner shelf respectively - the total packages being somewhat thinner at $c .3-11 \mathrm{~m}$. 


\section{5.d. Sequence TR4}

Sequence TR4 is lithologically similar to, but generally slightly thicker than, TR3. TR4 begins at an MRS that terminates the deposition of middle shelf limestone in central and western Spitsbergen, and inner to middle shelf limestone in NE Svalbard (Figs 5, 7). The initial flooding resulted in dark chert (facies 2 b) deposition characteristic of outer shelf environments at all sections apart from section E, where middle-shelf light cherts were established. As with sequence TR3, the basal dark cherts of TR4 are intensely bioturbated and contain abundant Thalassinoides and Skolithos burrows on their upper surfaces. Again, these probably reflect sediment starvation and the formation of firmgrounds at the onset of transgression in TR4. The dark chert (facies 2b) package that characterizes the TST component of TR4 ranges in thickness from just a few metres in NE Svalbard to as much as $45 \mathrm{~m}$ in the most expanded sections in western Spitsbergen (Fig. 7).

The MFS that caps the TST part of sequence TR4 sees the onset of a coarsening-upward sequence of typically inner and middle shelf facies including brachiopod-dominated, mixed-bioclastic, echinoderm-dominated and bryozoan-dominated limestones (mainly packstones, grainstones, and sandy floatstones and rudstones; facies 1a, 1c, 1d and 1e, sections F, TRN, E, H and S; Fig. 6d). The coarsening-upward trend at Festningen (section FN) is more subtle, because after the initial shift from dark cherts to light chert (facies 2a), dark chert deposition resumed, before finally giving way to mixed-bioclastic floatstones and rudstones typical of inner shelf environments. At section KF, the MFS at the base of the TST is subtler still, and is recorded by a transition from a fining-upward to a coarsening-upward trend within the pile of dark cherts (facies $2 b$ ).

The sequence TR4 RST package shows distinctive higher-order cyclicity that manifests as conspicuous lithological changes in some sections. At TRN, a several metre thick package of thinly bedded, dark shales and siltstones (facies 3c and 3d; Fig. 6c) is followed by a $c .15 \mathrm{~m}$ thick succession of thin- to mediumbedded bryozoan and echinoderm packstones, grainstones, floatstones and rudstones, arranged into at least six stacked coarsening- and thickening-upward cycles (Fig. 4).

Brachiopodal limestones, though relatively sparse in central and western Spitsbergen (sections F, FN, TRN, $\mathrm{KF}$ ) become increasingly common through sequence TR4 (Figs 4, 5), reflecting an overall gradual shallowing of the depositional area from outer and middle shelf to inner shelf environments upwards.

\section{5.e. Sequence TR5}

As with the TR2/TR3 sequence boundary, the basal contact of sequence TR5 is marked by intense glauconitization that was likely the result of sediment starvation in very shallow, nearshore environments around the end of the RST and at the onset of transgression (e.g. Boreen \& James, 1995; Blomeier et al. 2013). In central and western Spitsbergen (sections F, FN, TRN, KF) the MRS at the base of this sequence is succeeded once again by a thick pile of dark cherts (facies $2 \mathrm{~b}$ ) that overlie the fossiliferous (brachiopods, echinoderms, bryozoans) sandy cherts and grainstones, floatstones and rudstones that characterize the top of the preceding RST (Fig. 4). In NE Svalbard, the TST part of sequence TR5 is very thin in sections $\mathrm{E}$ and $\mathrm{S}$, comprising $1 \mathrm{~m}$ of black shale (facies $3 \mathrm{c}$ ) that overlies abundantly fossiliferous inner-shelf rudstones and floatstones (Fig. 5). The abrupt facies change at the MRS that caps these fossiliferous rocks heralds a rapid deepening in the area that led to sediment-starved conditions. Sequence TR5 is not exposed in section $\mathrm{H}$ due to subaerial exposure and erosion during a later sealevel fall (Fig. 7).

The MFS that marks the onset of regression in sequence TR 5 caps the black shales seen in NE Svalbard, and similar black shales that develop within the black chert in western Spitsbergen (sections F and FN). The overlying RST package records a coarsening-upward sequence through cherts into bioclastic wackestones to floatstones in all sections where this sequence is recorded. These limestones contain an abundant and diverse brachiopod fauna (around 27 individual genera and species; Bond et al. 2015) that disappears above this sequence in the basal decimetres of the overlying dark cherts of sequence TR6, a level that marks the Middle Permian (Capitanian) mass extinction.

\section{5.f. Sequences TR6 and TR7}

Sequences TR6 and TR7, comprising the transitional strata to the overlying latest Permian to Triassic Sassendalen Group, are exposed only in central and western Spitsbergen at Forkastningsdalen (F) and Festningen (FN). The MRS that tops the last brachiopodbearing wackestones of sequence TR5 is succeeded by a $c$. $4-5 \mathrm{~m}$ succession of transgressive dark cherts (facies 2b) of sequence TR6 that records the intraCapitanian Middle Permian mass extinction (Bond et al. 2015) and is capped by an MFS (Fig. 4). Above this MFS, a sharp grain-size increase is recorded by the development of $12 \mathrm{~m}$ of sandy cherts at Festningen, and c. $20 \mathrm{~m}$ of sandstones at Forkastningsdalen, which comprise the RST package of TR6. These detrital grains consist of quartz and significant amounts of abraded heavy mineral grains (rutile, zircon and apatite) together with common grains of potassium feldspar, chlorite and biotite. This assemblage of grain types persists to the top of sequence TR6 and reappears during sedimentation of TR7. This sequence is characterized by a paucity of fossils, presumably as a result of the globally significant Middle Permian mass extinction that occurred near its base.

Sequence TR7 begins at the MRS that caps sandy cherts at Festningen and is overlain by $c .10 \mathrm{~m}$ of black shales interbedded with thin, sandy cherts that together 
comprise the TST portion of this sequence (Figs 4, 7). The equivalent sequence at Forkastningsdalen is marked by unexposed intervals in the section, which we assume are soft shales that often have poor exposure in the Svalbard outcrops. Like TR6, this sequence is largely lacking in fossils. However, several thin, condensed fossiliferous horizons (bryozoans, bivalves and brachiopods) provide evidence of a brief recovery following the Middle Permian (Capitanian) extinction (Bond et al. 2015). The TST shales seen at Festningen are capped by an MFS that is overlain by sandy cherts that persist to the top of the Kapp Starostin Formation. At Forkastningsdalen, this RST is represented by sandstones. The topmost surface of the Formation in both sections is likely an MRS above which the sharp onset of mudstone deposition marks the base of the overlying latest Permian to Middle Triassic Sassendalen Group.

\section{Basin development}

\section{6.a. Svalbard}

A cross-section (Figs 1,7) correlating all seven sections illustrates the basin morphology during deposition of the Kapp Starostin Formation along a SW-NE transect across Spitsbergen and Nordaustlandet. The facies developments and thicknesses of the Formation are interpreted to reflect the palaeowater depth, which is a combination of the effects of local subsidence and sedimentation rate of the basin at each location (Ehrenberg et al. 2001) and eustatic variation. Accordingly, Festningen (section FN; Fig. 6e) represents the deepest part of the basin and its main depocentre. The basin shallows slightly to the southwest towards Forkastningsdalen (section F), and shallows significantly to the NE, where the basin assumes a shallow ramp characterized by a subdued relief (Fig. 7). Thickness trends in the basin fill appear to record an inherited structural control from Carboniferous rifting (Steel \& Worsley, 1984; Stemmerik \& Worsley, 1989), despite previous suggestions that by the Middle to Late Permian these structures had already been filled in (Johannessen \& Steel, 1992; Dallmann, 1999).

The thicker brachiopod- and bryozoan-dominated floatstone and rudstone deposits of the Vøringen Member at Eremitten and Hódbreen in NE Spitsbergen, and at Selanderneset on Nordaustlandet (sections E, H and S) at the NE end of the transect (Fig. 7), indicate a minor local depocentre, probably related to remnants of the Lomfjorden Trough, a smaller graben east of the Lomfjorden-Agardhbukta Fault Zone (Fig. 1). The Tålmodryggen and Kapp Fleur de Lys sections (TRN and KF) on Dickson Land in central Spitsbergen are positioned on the Nordfjorden High where the reduced accommodation space accounts for the generally thinner sedimentary successions compared to the surrounding areas (Steel \& Worsley, 1984; Ehrenberg et al. 2001).

Facies distributions and the general basin morphology provide an indication of proximal and distal areas. The sand-rich stratigraphy in the northeasternmost sections $(\mathrm{S}, \mathrm{H})$ suggests that a terrigenous source area was located in the vicinity of Nordaustlandet (Blomeier, Scheibner \& Forke, 2009). The common siltstone beds at Forkastningsdalen (section F; Figs 1, 7) suggest a second source of terrigenous sediment that was possibly related to erosion of the SørkappHornsund High that remained emergent until the end of the Permian (Dallmann, 1999).

\section{6.b. Regional comparison}

Comparison of the Kapp Starostin Formation with time-equivalent strata elsewhere along the northern margin of Pangaea reveals a similar depositional history. In the Sverdrup Basin of Arctic Canada, Beauchamp et al. (2009) recognized five complete T$\mathrm{R}$ cycles in a continuous sequence of black cherts, shales and siltstones that formed in the basin centre between the Early Permian and the earliest Triassic. The Artinskian-Kungurian Trappers Cove Formation includes one part-sequence (an RST - the underlying TST lies within the Sakmarian Hare Fiord Formation) and one complete T-R sequence. The latter begins with a transgression atop an MRS that marks the Artinskian-Kungurian boundary, and is therefore correlative with the development of the Vøringen Member at the base of the Kapp Starostin Formation in Svalbard (our sequence TR1). Just as in our TR1 sequence, Beauchamp et al. (2009) record a very thin TST in their basal Kungurian sequence, which soon gave way to a thicker overlying RST. The succeeding Kungurian to end-Capitanian van Hauen Formation of the Sverdrup Basin records two further complete T-R sequences. These probably correlate to our sequences TR2-TR5 and the basal part of TR6, based on the fact that the Middle Permian (intra-Capitanian) mass extinction in Svalbard manifests as the near-total loss of brachiopods near the base of that cycle. A middle-tolate Capitanian age for TR5 and TR6 in Svalbard is further supported by chemostratigraphy (Bond et al. 2015). Thus, if Beauchamp et al.'s (2009) age assignment for the van Hauen Formation is correct (based on a depauperate Mesogondolella conodont assemblage), four complete Kungurian to Capitanian T-R sequences occurred in Svalbard whilst only two occurred in the Sverdrup Basin during the same interval. Either local tectonics generated additional T-R sequences in Svalbard that are not recorded in the Sverdrup Basin, or the bounding surfaces are cryptic in the latter area and these sequences are unidentified. Above the van Hauen Formation, the Wuchiapingian-Changhsingian Black Stripe Formation and the latest Permian to Early Triassic Blind Fiord Formation record two further complete T-R sequences in the Sverdrup Basin; the same time interval in Svalbard also contains two comparable T-R sequences (TR6 and TR7) although we place at least part of the TST component of TR6 within the Capitanian for reasons given above. In Svalbard, the top of the Kapp Starostin Formation lies a few metres 
below the Permian-Triassic boundary and probably records an MRS at the top of an RST. In the Sverdrup Basin, this level is probably equivalent to the sequence boundary seen atop the Lindström Formation, in more proximal areas, whilst the unconformity passes into a correlative conformity within the Black Stripe Formation in distal areas (Beauchamp et al. 2009). The dark cherts of the uppermost Black Stripe are assigned to a TST, a unit that appears not to be represented in the Svalbard successions.

The sequence stratigraphic arrangement and sedimentary history is broadly similar between the two locations: five complete T-R sequences are recognized in the Sverdrup Basin from the base of the Kungurian to the Early Triassic; six complete sequences are seen during the same interval in Svalbard. Clearly, there is some discrepancy regarding the temporal placement of sequence boundaries that relates to the poor age control in both regions. Biostratigraphic correlation between the two areas is hampered by the paucity of conodonts. The dominance of the conodont Mesogondollela rosenkrantzi, and the absence of the Middle Permian forms M. phosphoriensis and M. bitteri, led Beauchamp et al. (2009) to assign a Wuchiapingian age to the Black Stripe Formation. However, the most recent taxonomic assessment considers $M$. rosenkrantzi to be a typical Capitanian taxon (Legler \& Schneider, 2008). If that is the case, the van Hauen / Black Stripe formational contact, assigned by Beauchamp et al. (2009) to the base of the Wuchiapingian, might actually be of an earlier Capitanian age. The first complete TST-RST package recorded by the Black Stripe Formation might be better placed within the Capitanian (rather than Wuchiapingian), in which case the early to middle Permian (Cisuralian-Guadalupian) sequence stratigraphic arrangement for the Sverdrup Basin matches that of Svalbard almost perfectly. However, this would create a discrepancy in the number of late Permian (Lopingian) cycles with either one or two T-R cycles recognized. Fully resolving the correlation of the T-R cycles on the Permian in the Svalbard and Canadian Arctic region awaits a breakthrough in either biostratigraphic or chemostratigraphic dating.

\section{Permian climatic, environmental and biotic changes}

The Late Palaeozoic saw dramatic climatic, environmental and palaeoceanographic changes, underpinned by a transition from a global icehouse in the Carboniferous to an extreme hothouse by the end of the Permian (e.g. Sun et al. 2012). High-amplitude, highfrequency, glacio-eustatic sea-level fluctuations have been attributed to periodic Gondwanan glaciations during the Late Carboniferous (Stemmerik, 1997, 2000). The subsequent deglaciation began sometime between the Sakmarian (Veevers \& Powell, 1987; Isbell et al. 2003) and the Kungurian (Chen et al. 2013). A late Artinskian to Kungurian deglaciation phase would be consistent with the record of the Kapp Starostin Formation. Thus, melting ice caps and the associated major sea-level rise would account for the widespread flooding of the palaeo-land surface that resulted in the Vøringen Member (sequence TR1) being deposited unconformably above the Gipshuken Formation (following a hiatus of unknown duration; Fig. 2). This major, second-order sea-level rise continued through at least sequences TR2 and TR3. The transgressiveregressive depositional sequences identified within the Kapp Starostin Formation are probably of lower amplitude than the presumed glacio-eustatic sea-level fluctuations of the Carboniferous and Early Permian that are recorded by the Wordiekammen and Gipshuken Formations.

Middle to Late Permian cyclicity in Svalbard has been ascribed to eustasy (Stemmerik, 1997; Rygel et al. 2008). However, whether the observed facies shifts on Svalbard and elsewhere in northwest Pangaea were the result of eustatic fluctuations and/or regional tectonic uplift or subsidence is difficult to untangle without better stratigraphic control. Comparison of our interpretation of relative sea-level for Svalbard with the global sea-level curve compiled by Haq \& Schutter (2008) reveals major discrepancies implying that the NW Pangaean record might be influenced by a tectonic signal. For example, the Haq \& Schutter (2008) curve shows no major Kungurian sea-level rise. Given that each shift in base level can be recognized across each of the sections in our study, local tectonic movements along the individual structural lineaments (e.g. Billefjorden Fault Zone, Lomfjorden Fault Zone, Raudfjorden Fault; Fig. 1) can be excluded as a controlling factor. Instead, the tectonic subsidence of extended parts of the entire shelf region might serve as possible explanation for the disparities between our regional sea-level history and the global curve.

The Middle Permian (Capitanian) mass extinction is recorded near the base of sequence TR6, when $>80 \%$ of brachiopod species were wiped out in Spitsbergen. These losses have been attributed to localized anoxia and ocean acidification (Bond et al. 2015) and to trace metal poisoning (Grasby et al. 2015, 2016). Thus, redox-sensitive trace metals such as $\mathrm{U}$, Mo and $\mathrm{V}$ become greatly enriched in the extinction interval (Bond et al. 2015; Grasby et al. 2015), as does mercury, which sees a prolonged period of enrichment culminating in a large spike at the Permian-Triassic boundary (Grasby et al. 2016). The absence of platform carbonates above TR5 in Spitsbergen and in age-equivalent strata across NW Pangaea is also consistent with a role for acidification (Bond et al. 2015).

Beauchamp \& Grasby (2012) suggested that the entire Permian Chert Event might have resulted from gradual shoaling of the lysocline and the calcite compensation depth, in response to progressive build-up of atmospheric $\mathrm{CO}_{2}$ during the Permian, and amplified by upwelling along the NW margin of Pangaea. Ocean acidification is postulated to have eradicated carbonate in favour of more resilient silica factories. However, 
the periodic accumulation of abundant and diverse calcareous skeletal remains (brachiopods, echinoderms, bryozoans etc.) in sometimes quite thick limestone deposits in the Sverdrup Basin (Beauchamp \& Grasby, 2012) and also in Svalbard suggests that the ocean $\mathrm{pH}$ was not consistently inhospitably low for carbonate producers. Beauchamp \& Grasby (2012) suggested that a 'temperature shock' (warming), particularly at the Permian-Triassic boundary, might have driven the lysocline deeper, allowing carbonates to resume accumulation in spite of low $\mathrm{pH}$ conditions. It is not clear how this can be reconciled with the Middle Permian extinction in which brachiopods (and all carbonates) disappear in Svalbard at a time of supposed warming - unless the magnitude of Middle Permian warming was not sufficient to drive the lysocline deep enough to counteract the enhanced input of atmospheric $\mathrm{CO}_{2}$ associated with contemporaneous large igneous province activity in China (e.g. Bond et al. 2015). In other words, did the deleterious effects of acidification (carbonate production crisis) outpace the counter-effects of warming (lysocline deepening) in this cool-water setting? Further testing is required to pinpoint the causal mechanisms involved in the Middle Permian mass extinction in Svalbard and beyond.

\section{Conclusions}

The mixed carbonate, siliceous and siliciclastic strata of the Kapp Starostin Formation (ArtinskianChanghsingian) were deposited in a cold to temperate, broad epicontinental shelf setting and display cyclicity of three different orders. Detailed facies analysis reveals seven third-order transgressive-regressive depositional sequences (TR1-TR7) that have been correlated across the depositional basin from western and central Spitsbergen to Nordaustlandet in the NE. These sequences, of c. 4-5 Ma average duration, are bound by prominent maximum regressive surfaces and are considered to be the result of relatively low-amplitude sea-level fluctuations superimposed on a second-order sea-level curve that controlled the overall stacking pattern. The basal Vøringen Member of the Kapp Starostin Formation saw deposition of bioclastic inner and middle shelf floatstones, rudstones and sandstones atop an extensive subaerial unconformity surface that provides evidence for widespread second-order flooding of vast karst, sabkha and peritidal platform areas. This major marine transgression is attributed either to the contemporaneous deglaciation of Gondwana or to regional tectonics (or a combination of both). In general, the older depositional sequences (TR1-TR3) record a net deepening across the basin (particularly noticeable in the shallower-water environments in NE Spitsbergen and Nordaustlandet) consistent with the overall second-order sea-level rise that continued into the Roadian. An overall thinning-upward and shallowing-upward stacking pattern characterizes sequences TR4-TR7, where sea-level rise decelerates and is finally outpaced by the filling of accommodation space within the depositional basin. Brachiopod losses associated with the Middle Permian mass extinction are observed in those sections where sequence TR6 is preserved, indicating basin-wide synchronicity of that event. The lack of carbonates in the post-TR5 strata is consistent with acidification as an extinction driver, and a decrease in the depth of the lysocline across Svalbard.

Acknowledgements. Thanks are given to Christian Scheibner, Michael Joachimski, Winfried Dallmann, Tatiana Grunt and the Organisation and Logistics Department of the Norwegian Polar Institute for support in the field. The technical staff at the universities of Amsterdam, Southampton, Oxford and Bremen are thanked for the preparation of numerous thin-sections for microfacies analysis. This work was supported by the Research Executive Agency (D. Bond, Marie Curie Intra-European Fellowship FP7-PEOPLE-2011-IEF300455), and the Natural Environment Research Council (D. Bond, grant number NE/J01799X/1; P. Wignall, grant number NE/I015817/1). VU Amsterdam provided financial assistance towards fieldwork at Kapp Fleur de Lys, including travel costs for R. Groen, sample shipping, thin-sectioning and geochemical analyses. We thank Benoit Beauchamp and Sten-Andreas Grundvåg for helpful reviews of an earlier version of this work, and two anonymous reviewers for reviews of the manuscript.

\section{References}

Beauchamp, B. \& Baud, A. 2002. Growth and demise of Permian biogenic chert along northwest Pangea: evidence for end-Permian collapse of thermohaline circulation. Palaeogeography, Palaeoclimatology, Palaeoeco$\log y$ 184(1-2), 37-63.

Beauchamp, B. \& Grasby, S. E. 2012. Permian lysocline shoaling and ocean acidification along NW Pangea led to carbonate eradication and chert expansion. Palaeogeography, Paleoclimatology, Palaeoecology 350-352, 73-90.

Beauchamp, B., Henderson, C. M. B., Grasby, S. E., Gates, L., Beatty, T., Utting, J. \& James, N. P. 2009. Late Permian sedimentation in the Sverdrup Basin, Canadian Arctic: the Lindström and Black Stripe formations. Canadian Society of Petroleum Geology Bulletin 57, 167-91.

Biernat, G. \& Birkenmajer, K. 1981. Permian brachiopods from the base of the Kapp Starostin Formation at Polakkfjellet, Spitsbergen. Studia Geologica Polonica 73, $7-24$.

Blomeier, D., Dustira, A. M., Forke, H. \& Scheibner, C. 2011. Environmental change in the Early Permian of NE Svalbard: from a warm-water carbonate platform (Gipshuken Formation) to a temperate, mixed siliciclastic-carbonate ramp (Kapp Starostin Formation). Facies 57(3), 493-523.

Blomeier, D., Dustira, A. M., Forke, H. \& Scheibner, C. 2013. Facies analysis and depositional environments of a storm-dominated, temperate to cold, mixed siliceouscarbonate ramp: the Permian Kapp Starostin Formation in NE Svalbard. Norwegian Journal of Geology 93(2), 75-93.

Blomeier, D., Scheibner, C. \& Forke, H. 2009. Facies arrangement and cyclostratigraphic architecture of a shallow-marine, warm-water carbonate platform: the Late Carboniferous Ny Friesland Platform in eastern 
Spitsbergen (Pyefjellet Beds, Wordiekammen Formation, Gipsdalen Group). Facies 55(2), 291-324.

Bond, D. P. G., Wignall, P. B., Joachimski, M. M., Sun, Y.-D., Savov, I., Grasby, S. E., Beauchamp, B. \& BlomeIER, D. P. G. 2015. An abrupt extinction in the Middle Permian (Capitanian) of the Boreal Realm (Spitsbergen) and its link to anoxia and acidification. Geological Society of America Bulletin 127(9-10), 1411-21.

BoreEn, T. D. \& JAMES, N. P. 1995. Stratigraphic sedimentology of Tertiary cool-water limestones, SE Australia. Journal of Sedimentary Research 65(1), 142-59.

Buggisch, W., Joachimski, M., Lützner, H., Thiedig, F. \& HüNEKE, H. 2001. Conodont stratigraphy of the Carboniferous and Permian strata from Brøggerhalvøya and the Billefjorden Trough (Svalbard). Geologisches Jahrbuch B91, 637-89.

CECCHI, M. 1993. Carbonate sequence stratigraphy: application to the determination of play-models in the Upper Paleozoic succession of the Barents Sea, offshore northern Norway. In Arctic Geology and Petroleum Potential (eds T. O. Vorren, E. Bergsager, Ø. A. Dahl-Stamnes, E. Holter, B. Johansen, E. Lie \& T. B. Lund), pp. 41938. Norwegian Petroleum Society, Special Publication no. 2.

Cecchi, M., Markello, J. \& Waite, L. 1995. Sequence stratigraphy architecture of CarboniferousPermian sedimentary systems of the Norwegian Barents Sea with comparison to coeval systems of the USA. In Sequence Stratigraphy on the Northwest European Margin, Proceedings of the Norwegian Petroleum Society Conference (eds R. J. Steel, V. L. Felt, E. P. Johannessen \& C. Mathieu), pp. 545-69. Norwegian Petroleum Society, Special Publication no. 5.

Chen, B., Joachimski, M. M., Shen, S.-Z., Lambert, L. L., LaI, X.-L., Wang, X.-D., Chen, J. \& Yuan, D.-X. 2013. Permian ice volume and palaeoclimate history: oxygen isotope proxies revisited. Gondwana Research 24, 77 89.

Chwieduk, E. 2007. Middle Permian rugose corals from the Kapp Starostin Formation, South Spitsbergen (Treskelen Peninsula). Acta Geologica Polonica 57(3), 281-304.

Coe, A. L., Bosence, D. W. J., Church, K. D., Flint, S. S., Howell, J. A. \& Wilson, R. C. L. 2003. The Sedimentary Record of Sea-Level Change. Cambridge/Milton Keynes: Cambridge University Press and the Open University, $287 \mathrm{pp}$.

Cohen, K. M., Finney, S. C., Gibbard, P. L. \& Fan, J.-X. 2013, updated. The ICS international chronostratigraphic chart. Episodes 36(3), 199-204.

Colpaert, A., Pickard, N., Mienert, J., Henriksen, L. B., RAfaElsen, B. \& ANDREASSEN, K. 2007. 3D seismic analysis of an Upper Palaeozoic carbonate succession of the Eastern Finnmark Platform area, Norwegian Barents Sea. Sedimentary Geology 197(1-2), 79-98.

Cutbill, J. L. \& Challinor, A. 1965. Revision of the stratigraphical scheme for the Carboniferous and Permian rocks of Spitsbergen and Bjørnøya. Geological Magazine 102(5), 418-39.

Dallmann, W. K. 1999. Lithostratigraphic Lexicon of Svalbard: Review and Recommendations for Nomenclature Use: Upper Palaeozoic to Quaternary Bedrock. Oslo: Norsk Polarinstitutt, $318 \mathrm{pp}$.

DunhaM, R. 1962. Classification of carbonate rocks according to depositional textures. In Classification of Carbonate Rocks - A Symposium (ed. W. E. Ham), pp. 108-21. American Association of Petroleum Geologists, Memoir no. 1.

Dustira, A. M., Wignall, P. B., JoAChimski, M., Blomeier, D., Hartkopf-Froder, C. \& Bond, D. P. G. 2013. Gradual onset of anoxia across the Permian-Triassic Boundary in Svalbard, Norway. Palaeogeography, Palaeoclimatology, Palaeoecology 374, 303-13.

EhrenberG, S. N., Nielsen, E. B., Svana, T. A. \& Stemmerik, L. 1998. Depositional evolution of the Finnmark carbonate platform, Barents Sea: results from wells 7128/6-1 and 7128/4-1. Norsk Geologisk Tidsskrift 78(3), 185-224.

Ehrenberg, S. N., Pickard, N. A. H., Henriksen, L. B., Svana, T. A., Gutteridge, P. \& Macdonald, D. 2001. A depositional and sequence stratigraphic model for cold-water, spiculitic strata based on the Kapp Starostin Formation (Permian) of Spitsbergen and equivalent deposits from the Barents Sea. American Association of Petroleum Geologists Bulletin 85(12), 2061-87.

Ehrenberg, S., Pickard, N., Svån̊̊, T., Nilsson, I. \& DAVYDOV, V. 2000. Sequence stratigraphy of the inner Finnmark carbonate platform (Upper CarboniferousPermian), Barents Sea - correlation between well 7128/6-1 and the shallow IKU cores. Norsk Geologisk Tidsskrift 80(2), 129-61.

Embry, A. \& JohANNESSEN, E. 1992. T-R sequence stratigraphy, facies analysis and reservoir distribution in the uppermost Triassic and Lower Jurassic succession, western Sverdrup Basin, Arctic Canada. In Arctic Geology and Petroleum Potential (eds T. O. Vorren, E. Bergsager, Ø. A. Dahl-Stamnes, E. Holter, B. Johansen, E. Lie \& T. B. Lund), pp. 121-46. Norwegian Petroleum Society, Special Publication no. 2.

Ezaki, Y., Kawamura, T. \& Nakamura, K. 1994. Kapp Starostin Formation in Spitsbergen: a sedimentary and faunal record of Late Permian palaeoenvironments in an Arctic region. In Pangea: Global Environments and Resources (eds A. F. Embry, B. Beauchamp \& D. J. Glass), pp. 647-55. Canadian Society of Petroleum Geologists, Memoir no. 17.

Grasby, S. E., Beauchamp, B., Bond, D. P. G., Wignall, P. B. \& SANEI, H. 2016. Mercury anomalies associated with three extinction events (Capitanian Crisis, Latest Permian Extinction and the Smithian/Spathian Extinction) in NW Pangea. Geological Magazine 153(2), 28597.

Grasby, S. E., Beauchamp, B., Bond, D. P. G., Wignall, P. B., Talavera, C., Galloway, J. M., Piepjohn, K., Reinhardt, L. \& Blomeier, D. P. G. 2015. Progressive environmental deterioration in NW Pangea leading to the latest Permian extinction. Geological Society of America Bulletin 127(9-10), 1331-47.

HaQ, B. U. \& Schutter, S. R. 2008. A chronology of Paleozoic sea-level changes. Science 322(5898), 64-68.

Hellem, T. \& Worsley, D. 1978. An outcrop of the Kapp Starostin Formation at Austjøkeltinden, Sørkapplandet. Norsk Polarinstitutt Årbok 1977, 340-3.

Isbell, J. L., Miller, M. F., Wolfe, K. L. \& Lenaker, P. A. 2003. Timing of late Paleozoic glaciation in Gondwana: was glaciation responsible for the development of Northern Hemisphere cyclothems? In Extreme Depositional Environments: Mega End Members in Geologic Time (eds M. A. Chan \& A. W. Archer), pp. 5-24. Geological Society of America, Special Paper no. 370 .

Johannessen, E. \& Steel, R. 1992. Mid-Carboniferous extension and rift-infill sequences in the Billefjorden 
Trough, Svalbard. Norsk Geologisk Tidsskrift 72(1), $35-48$.

Larssen, G. B., Elvebakk, G., Henriksen, L. B., Kristensen, S.-E., Nilsson, I., SAMUElSBERG, T. J., Tore, A. S., Stemmerik, L. \& Worsley, D. 2005. Upper Palaeozoic lithostratigraphy of the southern part of the Norwegian Barents Sea. Norges Geologiske Undersøkelse Bulletin 444, 3-45.

LAURITZEN, Ø. 1981a. Investigations of Carboniferous and Permian sediments in Svalbard. Norsk Polarinstitutt Skrifter 176, $47 \mathrm{pp}$.

LAURITZEN, Ø. 1981b. Undersøkelser i de sulfatførende sedimentene fra underperm i områdene nord for Isfjorden, Svalbard. Norsk Polarinstitutt Rapport 6, 23 pp.

Legler, B. \& SchneIder, J. W. 2008. Marine ingressions into the Middle/Late Permian saline lake of the Southern Permian Basin (Rotliegend, Northern Germany) possibly linked to sea-level highstands in the Arctic rift system. Palaeogeography, Palaeoclimatology, Palaeoecology 267, 102-14.

Mangerud, G. \& Konieczny, R. M. 1993. Palynology of the Permian succession of Spitsbergen, Svalbard. Polar Research 12(1), 65-93.

Mount, J. 1985. Mixed siliciclastic and carbonate sediments: a proposed first-order textural and compositional classification. Sedimentology 32(3), 435-42.

Murchey, B. L. \& Jones, D. L. 1992. A mid-Permian chert event: widespread deposition of biogenic siliceous sediments in coastal, island arc and oceanic basins. Palaeogeography, Palaeoclimatology, Palaeoecology 96(1-2), 161-74.

Nakamura, K., Kimura, G. \& Winsnes, T. 1987. Brachiopod zonation and age of the Permian Kapp Starostin Formation (Central Spitsbergen). Polar Research 5, 207-19.

NAKrem, H. A. 1988. Permian bryozoans from southern Spitsbergen and Bjørnøya. A review of bryozoans described by J. Malecki (1968, 1977). Polar Research 6, $113-21$.

NAKREM, H. A. 1991. Distribution of conodonts through the Permian succession of Svalbard. Geonytt 1, 38-9.

Nakrem, H. A., Nilsson, I. \& Mangerud, G. 1992. Permian biostratigraphy of Svalbard (Arctic Norway) - a review. International Geology Review 34(9), 933-59.

RonNEVIK, H. \& MotLAND, K. 1981. Geology of the Barents Sea. In Petroleum Geology of the Continental Shelf of North-West Europe (eds L. V. Illing \& G. D. Hobson), pp. 395-406. London: Institute of Petroleum.

Rygel, M. C., FIELding, C. R., Frank, T. D. \& BirgenHeIER, L. P. 2008. The magnitude of Late Paleozoic Glacioeustatic fluctuations: a synthesis. Journal of Sedimentary Research 78(8), 500-11.

SiedleckA, A. 1970. Investigations of Permian cherts and associated rocks in southern Spitsbergen. Norsk Polarinstitutt Skrifter 147, 86 pp.
Steel, R. J. \& Worsley, D. 1984. Svalbard's postCaledonian strata - an atlas of sedimentational patterns and palaeogeographic evolution. In Petroleum Geology of the North European Margin (ed. A. M. Spencer), pp. 109-35. London: Graham \& Trotman Ltd.

StemmeriK, L. 1988. Discussion. Brachiopod zonation and age of the Permian Kapp Starostin Formation (Central Spitsbergen). Polar Research 6, 179-80.

Stemmerik, L. 1997. Permian (Artinskian-Kazanian) coolwater carbonates in north Greenland, Svalbard and the western Barents Sea. In Cool-Water Carbonates (eds N. P. James \& J. A. D. Clarke), pp. 349-64. SEPM (Society for Sedimentary Geology), Special Publication no. 56.

Stemmerik, L. 2000. Late Palaeozoic evolution of the North Atlantic margin of Pangea. Palaeogeography, Palaeoclimatology, Palaeoecology 161(1-2), 95-126.

Stemmerik, L. \& Worsley, D. 1989. Late Palaeozoic sequence correlations, North Greenland, Svalbard and the Barents Shelf. In Correlation in Hydrocarbon Exploration (ed. J. D. Collinson), pp. 99-111. London: Graham \& Trotman Ltd., for the Norwegian Petroleum Society.

Stemmerik, L. \& Worsley, D. 2005. 30 years on - Arctic Upper Palaeozoic stratigraphy, depositional evolution and hydrocarbon prospectivity. Norwegian Journal of Geology 85(1-2), 151-68.

Sun, Y.-D., JOAChimski, M. M., Wignall, P. B., YAN, C.-B., Chen, Y.-L., Jiang, H.-S., Wang, L.-N. \& LaI, X.-L. 2012. Lethally hot temperatures during the Early Triassic greenhouse. Science 338, 366-70.

Szaniawski, H. \& Malkowski, K. 1979. Conodonts from the Kapp Starostin Formation (Permian) of Spitsbergen. Acta Geologica Polonica 24, 231-64.

TUCKER, M.E. 2003. Sedimentary Rocks in the Field. Chichester: Wiley and Sons, 237 pp.

VAIL, P. 1991. The stratigraphic signatures of tectonics, eustasy and sedimentology - an overview. In Cycles and Events in Stratigraphy (eds G. Einsele, W. Ricken \& A. Seilacher), pp. 617-59. Berlin: Springer

Veevers, J. T. \& Powell, C. M. 1987. Late Paleozoic glacial episodes in Gondwanaland reflected in transgressive-regressive depositional sequences in Euramerica. Geological Society of America Bulletin 98(4), 475-87.

Wentworth, C. K. 1922. A scale of grade and class terms for clastic sediments. The Journal of Geology 30(5), 377-92.

Wignall, P. B., Bond, D. P. G., Sun, Y.-D., Grasby, S. E., BeAUChamp, B., JOAChIMSKI, M. M. \& BlomeIER, D. P. G. 2016. Ultra-shallow-marine anoxia in an Early Triassic shallow-marine clastic ramp (Spitsbergen) and the suppression of benthic radiation. Geological Magazine 153(2), 316-31.

Wignall, P. B., Morante, R. \& Newton, R. 1998. The Permo-Triassic transition in Spitsbergen: $\delta^{13} C_{\text {org }}$ chemostratigraphy, $\mathrm{Fe}$ and $\mathrm{S}$ geochemistry, facies, fauna and trace fossils. Geological Magazine 135(1), 47-62. 